\title{
New host record for the enigmatic Neotropical mantidfly genus Anchieta Navás, 1909 (Neuroptera, Mantispidae), a mimic of wasps and stingless bees
}

\author{
Claus Rasmussen ${ }^{1}$ \& Adrian Ardila-Camacho ${ }^{2,3}$
}

\footnotetext{
1 Aarhus University (AU), Department of Agroecology. Tjele, Denmark. ORCID: http://orcid.org/0000-0003-1529-6548. E-mail: claus.rasmussen@agro.au.dk (corresponding author)

${ }^{2}$ Universidad Nacional Autónoma de México (UNAM), Instituto de Biología, Departamento de Zoología, Posgrado en Ciencias Biológicas. México, D.F., México. ORCID: http://orcid.org/0000-0002-3750-8671. E-mail: aardilac88@gmail.com

${ }^{3}$ Universidad INCCA de Colombia (UNINCCA), Departamento de Biología, Grupo de Investigación en Biotecnología y Medio Ambiente. Bogotá, D.C., Colombia.
}

\begin{abstract}
Species of Symphrasinae (Neuroptera: Mantispidae) are ectoparasitoids of larvae and pupae of holometabolous insects, primarily of Hymenoptera in their larval stages. Herein we present the third case of an association between the mantidfly genus Anchieta Navás, 1909 with the order Hymenoptera. The hymenopteran species attacked by the as of yet undescribed species of Anchieta is Montezumia dimidiata Saussure, 1852 (Vespidae: Eumeninae), a predacious wasp that constructs mud nests. The association was observed in Peruvian Amazonia (near Tarapoto, San Martín), after rearing the mantidflies from a wasp nest. The biology and mimicry pattern with stingless bees of the reared Anchieta species is discussed.
\end{abstract}

Keywords. Ectoparasitoids; Symphrasinae; Mimicry; Neotropics.

\section{INTRODUCTION}

The insect family Mantispidae (Neuroptera: Mantispoidea), commonly known as mantidflies are remarkable insects which have raptorial forelegs, a complex trait shared with the Rhachiberothidae, and the extinct Dipteromantispidae (Lambkin, 1986; Aspöck \& Mansell, 1994; Ohl, 2007; Liu et al., 2016; Engel et al., 2018). Their general appearance superficially resembles that of praying mantises (Insecta: Mantodea), but such condition is evidently a product of evolutionary convergence (Aspöck \& Aspöck, 2007). Despite the interesting morphology of the adults, the mimicry with toxic or poisonous insects exhibited by several genera, and the complex postembryonic development (hypermetamorphis) (Brauer, 1852, 1869, 1887) - in which their larvae may be ectoparasitoids, parasites, and spider-egg predators -, many aspects of mantidflies biology and taxonomy still need research (Redborg \& MacLeod, 1985; Eggleton \& Belshaw, 1992; Redborg, 1998; Snyman et al., 2020).

The Mantispidae species for which the biology is better known belong to the subfamily Mantispinae, whose larvae feed primarily on spi- der eggs, yet sometimes can feed temporarily on spider hemolymph, when the eggs are unavailable (Redborg \& MacLeod, 1985; Redborg, 1998). Of the remaining smaller subfamilies, the New World Symphrasinae, which is composed of three extant genera, Anchieta Navás, 1909, Plega Navás, 1928 and Trichoscelia Westwood, 1852 have been reported as ectoparasitoids of larval Hymenoptera, Lepidoptera, Coleoptera, and possibly Diptera (Redborg, 1998; Hook et al., 2010; Maia-Silva et al., 2013; Snyman et al., 2020). Most of the hymenopteran records has been on Polybia Lepeletier, 1836 (Vespidae: White, 1841; Walker, 1853; Rogenhofer, 1862; Smith, 1863; Westwood, 1867; Hagen, 1877; Brauer, 1887; Berg, 1899; Parfin, 1958; Richards, 1978; Penny, 1982; Dejan \& Canard, 1990), but also apoid wasps of the genus Trypoxylon Latreille, 1796 (Crabronidae: Parker \& Stange, 1965; Buys, 2008), as well as various solitary bees, such as Melitoma Lepeletier \& Serville, 1828 (Apidae: Linsley \& MacSwain, 1955; Linsley et al., 1980), Hylaeus Fabricius, 1793 (Colletidae: Hook et al., 2010), and Megachile Latreille, 1802 (Megachilidae: Parker \& Stange, 1965).

Both direct observation (Dejan \& Canard, 1990) and circumstantial evidence (Linsley et al., 1980; 
Hook et al., 2010) suggest that symphrasine females deposits their eggs near the host nest entrance, or near individual cells within the host nest. The newly hatched first instar mantispids then migrates into the cells while it is being provisioned, later the larva becomes attached to the surface of the host and remains attached until the host dies. The mantispid larvae feed on the host until completion of development when a mobile pupa chews its way out of the cocoon and emerges as a mobile pharate adult.

Anchieta is the smallest genus of Symphrasinae, including eight little-known species found from Panama to Southern Brazil, with most of the species distributed across the Amazon rainforest (Ardila-Camacho et al., 2018; Oswald, 2020). The genus is remarkable among the symphrasine genera, as all of the species mimic different groups of Hymenoptera (i.e., Apidae (Meliponini), Vespidae, and Braconidae), and is distinguished from other genera of the subfamily by having a prominent, blunt process on the fore trochanter, and a straight anterior radial cell of forewing (Ardila-Camacho et al., 2018). The only previously reported host of Anchieta was the mud dauber Trypoxylon (Trypargilum) aestivale Richards, 1934 (Hymenoptera: Crabronidae) (Buys, 2008). From the mud nest of this wasp species, a single specimen of A. fumosella (Westwood, 1867) was reared out and presumably it had fed on the last instar larva or on the pupa of the wasp (Buys, 2008). Recently, further unspecified associations with wasps or bees were reported by Araújo et al. (2021).

Based on specimens of a new Anchieta species - referred here as Anchieta sp. nov. - which attacked mud nests of $M$. dimidiata, the purpose of the present paper is to provide the only second known and identified host record for the genus, as well as scattered observations on the biology and the mimicking of Anchieta.

\section{MATERIAL AND METHODS}

Irregular surveys for nests of Hymenoptera have been performed in San Martin since 2002 by the first author, including near "Urku Estudios Amazonicos" educational center close to the Boca Toma of Rio Shilcayo, Tarapoto, Peru $\left(06.4595^{\circ} \mathrm{S}, 76.3512^{\circ} \mathrm{W}, 410 \mathrm{~m}\right.$ a.s.I.). The locality is adjacent to the local water reservoir of Tarapoto, within $100 \mathrm{~m}$ of the Shilcayo river, and represents an interesting transition area between lowland rainforest and lower montane rain forest, or cloud forest, in Peru. The high precipitation associated with the abrupt elevational gradient in the region of the "Cordillera Escalera" result in great environmental heterogeneity and a unique biological diversity (e.g., Rasmussen \& Skov, 2006; Rasmussen, 2009; Rasmussen \& Gonzalez, 2009). On this location a single adult female of the potter wasp Montezumia dimidiata Saussure, 1852 (Vespidae: Eumeninae) was observed resting on a mud nest plastered beneath a roof tile (Fig. 1A). The nest was collected the same day on July $10^{\text {th }}, 2012$ and left in a jar awaiting emergence (Figs. 1B, 1C). All observations hereafter were made as insects emerged from the jar left at room temperature.

Species identification of the emerging Anchieta was made by dissecting and clearing the abdomen, following the standard procedures with 10\% Potassium Hydroxide solution $(\mathrm{KOH})$. The external morphology and genital sclerites were compared with the types of all known species of Anchieta. All these structures were examined using a Zeiss Dicovery V8 stereomicroscope. Specimens were deposited at Museo de Historia Natural de Lima, Peru (MUSM) and Museum für Naturkunde, der Humboldt-Universität, Berlin, Germany (ZMB).

\section{RESULTS AND DISCUSSION}

\section{Biology}

The $M$. dimidiata nest was smaller but otherwise similar to two nests of the same species described from Colombia by Evans (1973), including the observation that individual cells were not obvious due to irregular plastering of mud covering the surface of the nest. The collected nest contained a total of five cells, three basal cells in parallel and adhered to the surface of the tile, followed by two additional cells in a second outer row. Of the three basal cells, the first was empty, possible damaged during the collection of the nest, and the second cell was the only open and had a small $4 \mathrm{~mm}$ long turret at the entrance (Fig. 1B). No provision, egg, or larvae were observed in that cell, and it is possible that this cell was either ready for provisioning by the founding female wasp observed resting on the nest or, that the female outside was instead a recently emerged wasp from this very cell. However, the presence of a turret suggests that the female outside was the founding female, although it is unclear why the last cell to be provisioned would be the most basal cell in her construction. The last of the basal row cells is the one where all five mantispid cocoons were encountered together (Figs. 1C, 1E). The second row of cells both contained wasps, with one female $M$. dimidiata wasp later emerged while the wasp in the last cell was found dead. Cells measured internally about 9 by $24 \mathrm{~mm}$. No provision for the wasps were encountered in this nest, but Evans (1973) reported microlepidoptera species as prey for $M$. dimidiata.

No egg chorions were found on the smooth inner walls of the cell and it is not clear when or where the eggs of the five mantispids were deposited, but the nest was collected on July $10^{\text {th }}, 2012$, and contained by then five cocoons with content. The adult mantispids emerged July $19^{\text {th }}$ (female, Fig. 1D), July $22^{\text {nd }}$ (male), July $28^{\text {th }}$ (male, Fig. 2A), September $6^{\text {th }}$ (male pupae, died), September $8^{\text {th }}$ (male, Figs. $2 \mathrm{C}-2 \mathrm{G}$ ). This is $9,12,18,58$, and 60 days after the encounter and collection of the nest. The emerging mantispids are identified as Anchieta, but does not correspond to any of the eight known species of the genus and will be described as a new species by Ardila-Camacho in a forthcoming taxonomic revision of the genus, so here we treat it as Anchieta sp. nov. 
The mantispid cocoons (Fig. 2B) were only lightly attached to the cell wall and to each other, made of loosely woven silken threads, which upon maturing turned darker yellow until reaching the coloration of the pupae, including two dark spots presumably marking the eyes. The size of the cocoons were 6 by $3 \mathrm{~mm}$ (the four males) and a single larger, 8 by $4 \mathrm{~mm}$ (the single female), made from a darker (or older) thread.
Two of the emerging Anchieta sp. nov. were observed first actively moving around as exarate pupae or pharate adults (Fig. 2C-2E), but within hours of leaving the cocoon, shed the exuviae and then rested for hours (Fig. 2E) until the cuticle and wings had completely hardened and darkened (compare the coloration of the hind leg from the same individual in Figs. $2 \mathrm{E}$ and $2 \mathrm{G}$ ). One of the exarate pupae did not survive and died be-

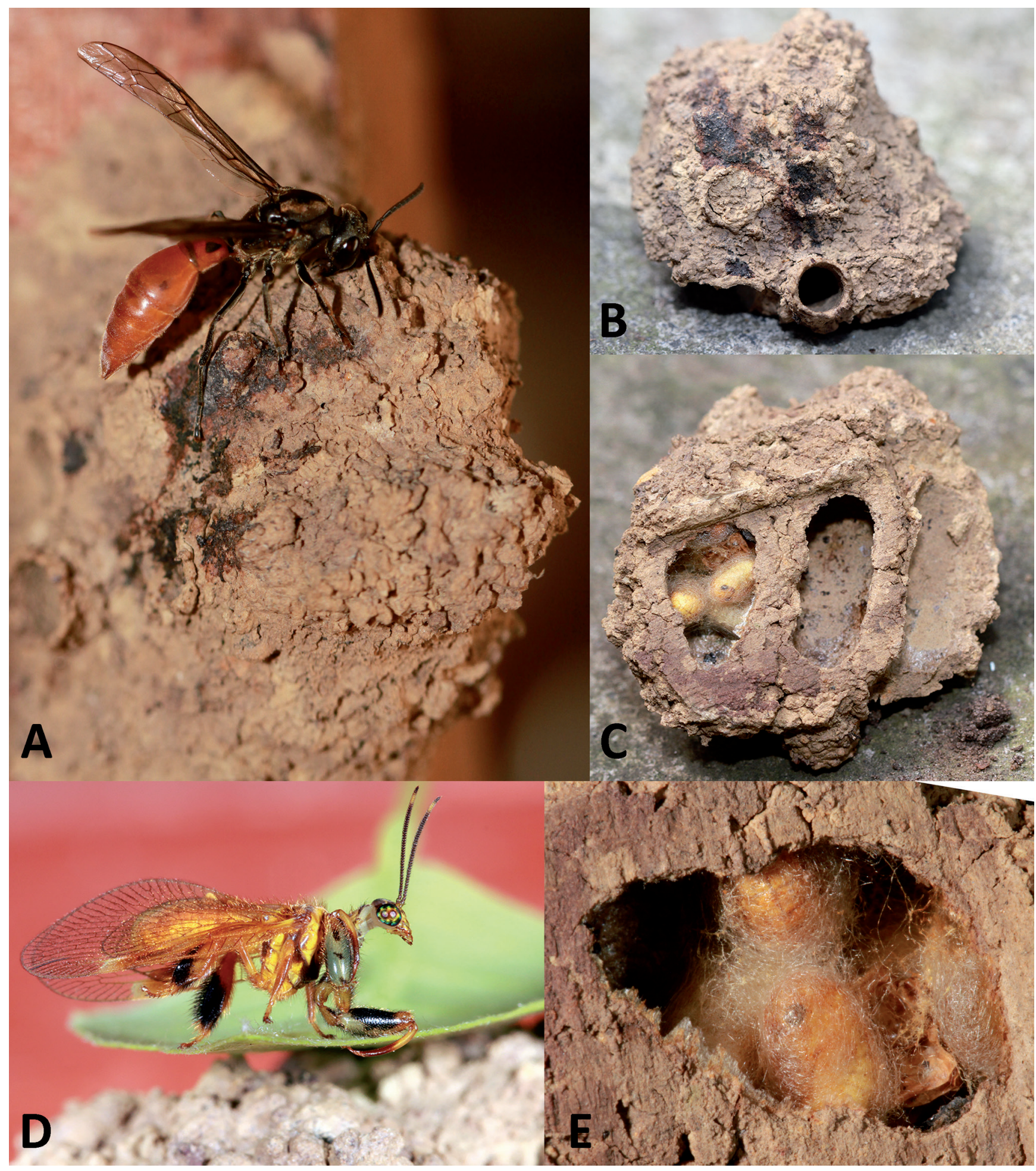

Figure 1. The potter wasp nest with the possible founding female Montezumia dimidiata (Hymenoptera: Vespidae), from which five specimens of Anchieta sp. nov. (Neuroptera: Mantispidae) were reared out (A). The M. dimidiata nest with a single open cell, with turret, shortly after the collection (B). The nest with three exposed cells (one damaged), including the left cell contained five pupae of Anchieta sp. nov. at different developmental stages. Five days later the specimen in the upper cocoon emerged (C). The first Anchieta sp. nov. (female) to emerge (D). The cell now contains four live pupae of Anchieta sp. nov. at different developmental stages (E). 

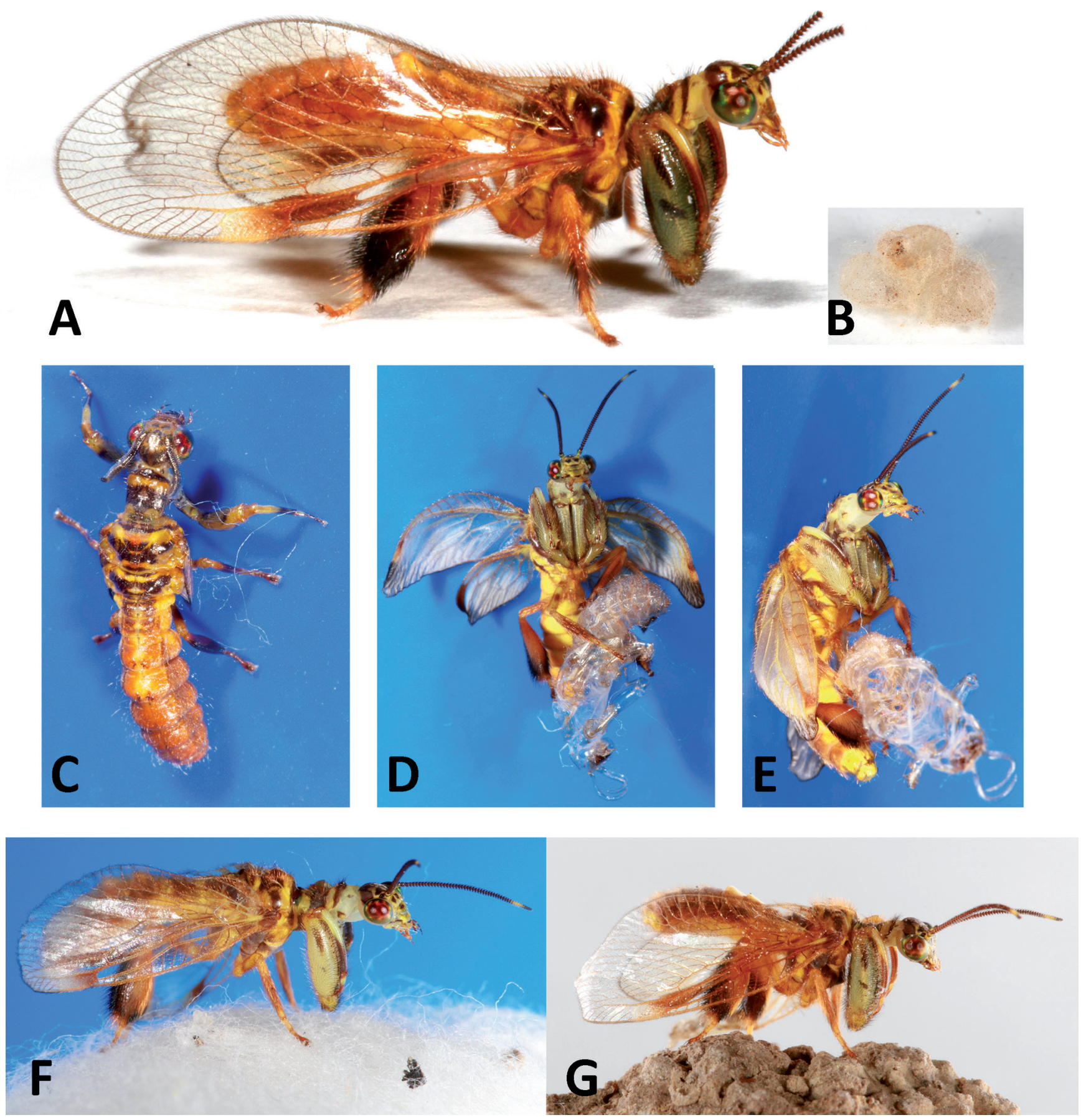

Figure 2. The third Anchieta sp. nov. (Neuroptera: Mantispidae), a male, to emerge from the nest of Montezumia dimidiata (Hymenoptera: Vespidae) (A). The empty cocoons from Anchieta sp. nov. (B). The last, and fifth, Anchieta sp. nov. to emerge, a male. This demonstrates that the pharate specimen is active and moving as a pupa (C). The specimen is removing the exuvia from the prepupa. Notice that the wings are still soft and bent $(C$ and $D)$. The same specimen is now waiting for the wings to strengthen few minutes after having shred the exuvia (F). The same specimen with hardened wing. Notice that the wing did not display perfectly (G).

fore molting, although it can be observed that a complete adult is trapped beneath the exuviae of the pupae. While active and moving exarate pupae were not observed for the specimens, the exuviae were always found away from the nest cell and the cocoon where they had emerged, suggesting that they would leave the pupae with the exuviae still attached. The actual shedding of the exuvia took less than ten minutes on the single instance when it was observed, that is from the individual began moving and until the exuvia was removed.

\section{Mimicking}

An interesting observation on this new species was the immediate confusion of its identity by the first author upon emergence. Having collected the nest of a known species of potter wasp and expecting the emergence of this wasp, the surprise was that the first emerging insect had a close resemblance to the social stingless bee, Ptilotrigona lurida (Smith, 1854), both with respect to size, coloration of wings and body, and down to the imitation of the expanded hind legs, resembling the pollen basket 
of corbiculate bees (Engel \& Rasmussen 2021). Dissected individuals are compared side by side in Figs. 3A-3B. The ovoid, light orange forefemur with black markings on the outer surface, plus the short and narrow hind wing resemble the compound eye and the overall shape of the hindwing of the bee, respectively. The first author has caught these bees commonly in the area, but only in forested parts, such as the type locality for Anchieta sp. nov. It has previously been reported that some species of Anchieta mimic stingless bees (Penny, 1982; Penny \& Costa, 1984; Hogue, 1993), social wasps (e.g., A. fumosella in Buys, 2008) or braconids equipped with repugnant glands (e.g., A. fasciatella (Westwood, 1867) in ArdilaCamacho \& García, 2015). Aggressive social paper wasps are common models for mantispids throughout the world (Batra, 1972; Boyden, 1983; Beck, 2005; Snyman et al., 2020), and individual species have been shown to form distinct color morph mimics that traces the local wasp fauna through polymorphism (Batra, 1972; Opler, 1981). While a Vespidae wasp model is observed in a single species (i.e., yellow and black morph of $A$. fumosella), most species of Anchieta appear to closely resemble either Ptilotrigona Moure, 1951 (e.g., A. apiculasaeva Thouvenot, 2009, A. bella (Westwood, 1867), A. eurydella (Westwood, 1867), A. partheniella (Westwood, 1867), A. remipes (Gerstaecker, 1888), and Anchieta sp. nov.) or Trigona Jurine, 1807 (e.g., dark morph of A. fumoselIa, and $A$. notha (Erichson, 1830)) stingless bees. For instance, $A$. notha co-occur with Trigona spinipes (Fabricius, 1793), while a Colombian specimen of Anchieta eurydella from Amacayacu (Amazonas, Colombia) was sweeped flying with a group of stingless bees, including Trigona dallatorreana Friese, 1900, Plebeia sp. and Nogueirapis butteli (Friese, 1900) with T. dallatorreana possibly the model in a protective Batesian mimicry system. These species of Ptilotrigona and Trigona form large nests and are amongst the most aggressive of all stingless bees, in part due to relatively large-sized and strong mandibles with pointed teeth (Kerr, 1951; Wille \& Michener, 1973; Rasmussen \& Camargo, 2008). The bees will attack in swarm near the nest but are unaggressive away from the nest. This is rather intriguing, as in order to provide an efficient model phenotype in a mimicry system, they also need to be noxious to predators away from the nest. However, stingless bees often carry sticky resins on the
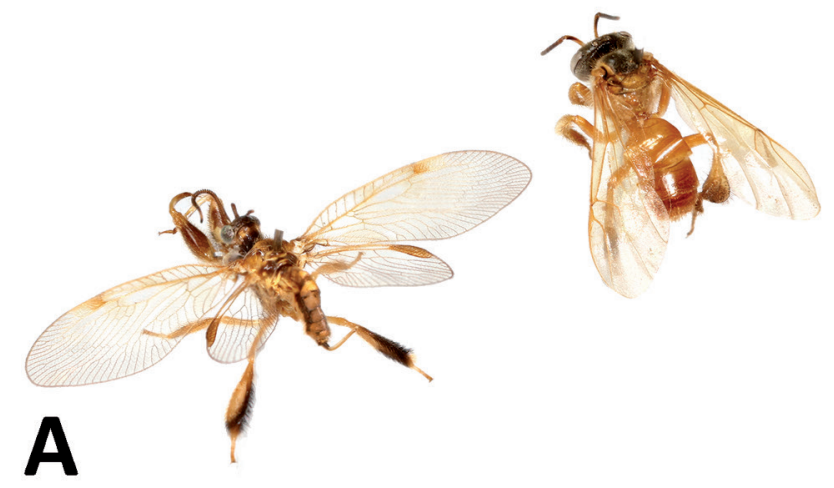

legs, have distasteful and foul-smelling mandibular gland substances (Kerr, 1951; Smith \& Roubik, 1983; Roubik, 1989), and plant-originated terpenes on the bees' cuticles (Lehmberg et al., 2008; Leonhardt et al., 2009) which makes them noxious and less prone to predation, as well as an efficient model for mimicry systems. In the case of Anchieta, the biological mimicry system is obviously Batesian, with the stingless bees being the model phenotype and Anchieta the mimic.

Several insect groups mimic in part stingless bees; this includes hover flies in South and Central America (Diptera: Syrphidae: Ubristes s.l. Walker, 1852, Rhoga Walker, 1857, Copestylum Macquart, 1846, Ocyptamus Macquart, 1834, a.o.) (Salt, 1929; Olesen, 1991; Cheng \& Thompson, 2008; Reemer, 2010, 2012), horse flies (Tabanidae: Lepiselaga Macquart, 1938) (Brown et al., 2009), long-horn beetles (Coleoptera: Cerambycidae: Epimelitta Bates, 1870, Pseudophygopoda Tavakilian \& Peñaherrera-Leiva, 2007, Epania Pascoe, 1858, a.o.) (Wallace, 1867; Bates, 1870; Shelford, 1902; Schwarz, 1948; Linsley, 1959; Chemsak \& Linsley, 1979), and maybe even parasitic wasps (Hymenoptera: Braconidae: Hartemita Cameron, 1910) (Long \& Achterberg, 2011). A different strategy are found among certain predatory assassin bugs (Heteroptera: Reduviidae: Apiomerus Hahn, 1831, Notocyrtus Burmeister, 1835, Pahabengkakia Miller, 1941, a.o.) that resemble stingless bees (Kerr, 1951; Jackson, 1973; Johnson, 1983; Roubik, 1989; Gonzales-Bustamante, 1995; Silva \& Gil-Santana, 2004; Wattanachaiyingcharoen \& Jongjitvimol, 2007; Alvarez et al., 2019). This is possibly in order to approach and prey on flower visiting insects.

While stingless bees are one possible model, other bees such as e.g., Paratetrapedia Moure, 1941 and Tetrapedia Klug, 1810 (Hymenoptera: Apidae) repeat the same coloration pattern (Kerr, 1951; Aguiar \& Melo, 2011), and might form a mimicry complex, and a Müllerian mimicry model to the stingless bees. Paratetrapedia females have a sting and are able to defend themselves and their hind legs are expanded due to dense pubescence. However, suggestive of the stingless bees being the model phenotype for all mimics is the fact that stingless bees are the most abundant of the species. To provide a classical workable mimicry system imitators are always less numerous in individuals (Wallace,

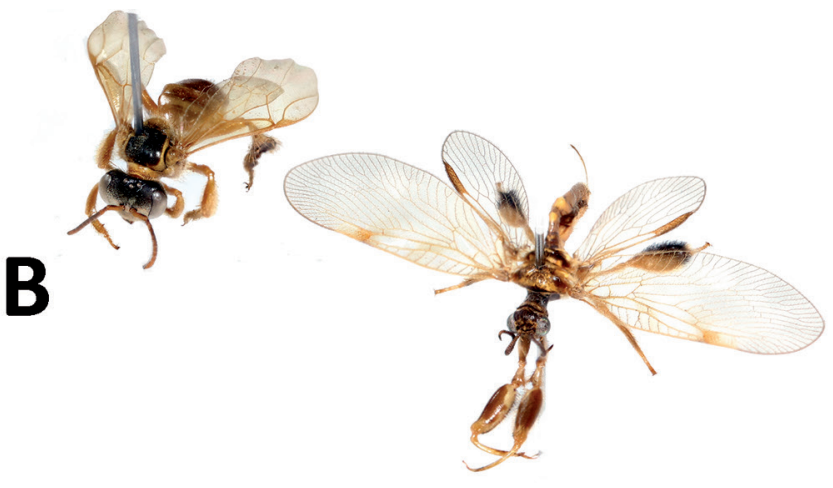

Figure 3. Anchieta sp. nov. and Ptilotrigona lurida (Smith, 1854) next to each other. The former with the abdomen inflated following the dried up condition (A and $B$ ). 
1889; Poulton, 1890). Other bees mimicking stingless bees of the genus Melipona Illiger, 1806 are for example Megachile Latreille, 1802 and Anthidium Belavadi, 2017 (Megachilidae) (C. Rasmussen, pers. obs.).

\section{ACKNOWLEDGMENTS}

Daniel Vecco and the rest of the staff at Urku are thanked for encouraging research on the area. In addition, Michael Ohl inspired the collaboration here and identified the specimen of Anchieta eurydella, Josef Gusenleitner and Bolívar Rafael Garcete-Barrett identified the Montezumia dimidiata wasp, Antonio Aguiar, Hélcio Gil, Menno Reemer, Keith Bayless and Doug Yanega helped with mimicry references, and Victor Gonzalez helped with literature for which we are grateful. AAC acknowledges Posgrado en Ciencias Biológicas, UNAM, for its support during his studies, and Consejo Nacional de Ciencia y Tecnología (CONACyT) for the financial support through a doctoral scholarship. The second author also wants to express sincere thanks to Atilano Contreras-Ramos of Intituto de Biología, UNAM for his support during all stages of his doctorate. Specimens were collected under permit Nr. 0356-2012-AG-DGFFS-DGEFFS.

\section{AUTHORS' CONTRIBUTIONS}

C.R.: Fieldwork, Rearing, Methodology, Writing - original draft, Writing - review \& editing. A.A.-C.: Identificaton, Methology, Writing - review \& editing. Both authors actively participated in the discussion of the results, they reviewed and approved the final version of the paper. Authors declare there are no conflicts of interest.

\section{REFERENCES}

Aguiar, A.J.C. \& Melo, G.A.R. 2011. Revision and phylogeny of the bee genus Paratetrapedia Moure, with description of a new genus from the Andean Cordillera (Hymenoptera, Apidae, Tapinotaspidini). Zoological Journal of the Linnean Society, 162: 351-442.

Alvarez, L.J.; Zamudio, F. \& Melo, M.C. 2019. Eating with the enemy? Mimic complex between a stingless bee and assasin bugs. Papéis Avulsos de Zoologia, 59(27): e20195927. DOI

Araújo, G.J.; Storck-Tonon, D.; Dáttilo, W. \& Izzo, T.J. 2021. Is being green what matters? Functional diversity of cavity-nesting bees and wasps, and their interaction networks with parasites in different reforestation types in Amazonia. Insect Conservation and Diversity. DOI

Ardila-Camacho, A. \& García, A. 2015. Mantidflies of Colombia (Neuroptera, Mantispidae). Zootaxa, 3937: 401-455.

Ardila-Camacho, A.; Calle Tobón, A.; Wolff, M. \& Stange, L.A. 2018. New species and new distributional records of Neotropical Mantispidae (Insecta: Neuroptera). Zootaxa, 4413: 295-324.

Aspöck, U. \& Aspöck, H. 2007. Verbliebene Vielfalt vergangener Blüte. Zur Evolution, Phylogenie und Biodiversität der Neuropterida (Insecta: Endopterygota). Denisia, 20: 451-516. https://archive.org/details/ denisia-20-451-516.
Aspöck, U. \& Mansell, M.W. 1994. A revision of the family Rhachiberothidae Tjeder, 1959, stat. n. (Neuroptera). Systematic Entomology, 19(3): 181-206.

Bates, H.W. 1870. Contributions to an insect fauna of the Amazon Valley (Coleoptera, Cerambycidae). Transactions of the Entomological Society of London, 18: 243-335.

Batra, S.W.T. 1972. Notes on the behavior and ecology of the mantispid, Climaciella brunnea occidentalis. Journal of the Kansas Entomological Society, 45(3): 334-340.

Beck, J. 2005. Wasp-mimicking Mantispidae (Insecta: Neuroptera) from Sabah, Malaysia. Sepilok Bulletin, 3: 37-40.

Berg, C. 1899. Las mantíspidos de la República Argentina. Comunicaciones del Museo nacional de Buenos Aires, 1: 139-145.

Boyden, T.C. 1983. Mimicry, predation and potential pollination by the mantispid, Climaciella brunnea var. instabilis (Say) (Mantispidae: Neuroptera). Journal of the New York Entomological Society, 91(4): 508-511.

Brauer, F. 1852. Verwandlungsgeschichte der Mantispa pagana. Archiv für Naturgeschichte, 18(1): 1-2.

Brauer, F. 1869. Beschreibung der Verwandlungsgeschichte der Mantispa styriaca Poda und Betrachtungen über die sogenannte Hypermetamorphose Fabre's. Verhandlungen der Kaiserlich-Königlichen Zoologisch-Botanischen Gesellschaft in Wien, 19: 831-840.

Brauer, F. 1887. Beitrag zur Kenntnis der Verwandlung der MantispidenGattung Symphrasis Hg. Zoologischer Anzeiger, 10: 212-218.

Brown, B.V.; Borkent, A.; Cumming, J.M.; Wood, D.M.; Woodley, N.E. \& Zumbado, M.A. 2009. Manual of Central American Diptera. Ottawa, NRC Research Press.

Buys, S.C. 2008. Observations on the biology of Anchieta fumosella (Westwood 1867) (Neuroptera Mantispidae) from Brazil. Tropical Zoology, 21: 91-95.

Chemsak, J.A. \& Linsley, E.G. 1979. Review of the Rhinotragini of Mexico (Coleoptera: Cerambycidae). Proceedings of the California Academy of Sciences, 42: 69-85.

Cheng, X.-Y.\& Thompson, F.C. 2008. A generic conspectus of the Microdontinae (Diptera: Syrphidae) with the description of two new genera from Africa and China. Zootaxa, 1879: 21-48.

Dejan, A. \& Canard, M. 1990. Reproductive behaviour of Trichoscelia santareni (Navás) (Neuroptera: Mantispidae) and parasitization of the colonies of Polybia diguetana R. du Buysson (Hymenoptera: Vespidae). Neuroptera International, 6: 19-26.

Eggleton, P. \& Belshaw, R. 1992. Insect parasitoids - an evolutionary overview. Philosophical Transactions of the Royal Society B - Biological Sciences, 1279: 1-20.

Engel, M.S. \& Rasmussen, C. 2021. Corbiculate Bees. In: Starr, C.K. (Ed.). Encyclopedia of social insects. Cham, Switzerland, Springer. p. 1-9.

Engel, M.S.; Winterton, S.L. \& Breitkreuz, L.C.V. 2018. Phylogeny and evolution of Neuropterida: where have wings of lace taken us? Annual Review of Entomology, 63: 531-551.

Evans, H.E. 1973. Notes on the nests of Montezumia (Hymenoptera, Eumenidae). Entomological News, 84(9): 285-290.

Gonzales-Bustamante, L.E. 1995. Apiomerus sp. (Hemiptera: Reduviidae) mimeta de Trigona trinidadensis (Hymenoptera: Apidae). Revista Peruana de Entomología, 37: 115-116.

Hagen, H.A. 1877. Symphrasis, eine neue Mantispiden-Gattung. Entomologische Zeitung, 38: 208-211.

Hogue, C.L. 1993. Latin American insects and entomology. Berkeley, CA, University of California Press.

Hook, A.W., Oswald, J.D. \& Neff, J.L. 2010. Plega hagenella (Neuroptera: Mantispidae) parasitism of Hylaeus (Hylaeopsis) sp. (Hymenoptera: 
Colletidae) reusing nests of Trypoxylon manni (Hymenoptera: (rabronidae) in Trinidad. Journal of Hymenoptera Research, 19: 77-83.

Jackson, J.F. 1973. Mimicry of Trigona bees by a reduviid (Hemiptera) from British Honduras. Florida Entomologist, 56(3): 200-202.

Johnson, L.K. 1983. Apiomerus pictipes (Reduvio, Chinche asesina, assassin bug). In: Janzen, D.H. (Ed.). Costa Rican natural history. Chicago, Chicago University Press. p. 684-687.

Kerr, W.E. 1951. Bases para o estudo da genética de populações dos Hymenoptera em geral e dos Apinae sociais em particular. Anais da Escola Superior de Agricultura "Luiz de Queiroz", 8: 219-354.

Lambkin, K.J. 1986. A revision of the Australian Mantispidae (Insecta: Neuroptera) with a contribution to the classification of the family. I. General and Drepanicinae. Australian Journal of Zoology, Supplementary Series, 116: 1-142.

Lehmberg, L.; Dworschak, K. \& Blüthgen, N. 2008. Defensive behavior and chemical deterrence against ants in the stingless bee genus Trigona (Apidae, Meliponini). Journal of Apicultural Research, 47: 17-21.

Leonhardt, S.D.; Blüthgen, N. \& Schmitt, T. 2009. Smelling like resin: terpenoids account for species-specific cuticular profiles in SoutheastAsian stingless bees. Insectes Sociaux, 56: 157-170.

Linsley, E.G. 1959. Mimetic form and coloration in the Cerambycidae (Coleoptera). Annals of the Entomological Society of America, 52: 125-131.

Linsley, E.G. \& MacSwain, J.W. 1955. Two new species of Plega from Mexico (Neuroptera, Mantispidae). Pan-Pacific Entomologist, 31: 15-19.

Linsley, E.G.; MacSwain, J.W. \& Michener, C.D. 1980. Nesting biology and associates of Melitoma. University of California Publications in Entomology, 90: 1-45.

Liu, X.-y.; Lu, X.-m. \& Zhang, W.-w. 2016. Halteriomantispa grimaldii gen. et sp. nov.: a new genus and species of the family Dipteromantispidae (Insecta: Neuroptera) from the mid-Cretaceous amber of Myanmar. Zoological Systematics, 41: 165-172.

Long, K.D. \& Achterberg, C. v. 2011. Review of the genus Hartemita Cameron, 1910 (Hymenoptera, Braconidae, (ardiochilinae), with the description of six new species from Vietnam. ZooKeys, 102: 13-40.

Maia-Silva, C.; Hrncir, M.; Koedam, D.; Machado, R.J.P.; Imperatriz Fonseca, V.L. 2013. Out with the garbage: the parastic strategy of the mantisfly Plega hagenella mass-infesting colonies of the eusocial bee Melipona subnitida in northeastern Brazil. Naturwissenschaften, 100: 101-105.

Ohl, M. 2007. Towards a global inventory of Mantispidae - the state-of-theart in mantispid taxonomy. Annali del Museo Civico di Storia Naturale di Ferrara, 8: 79-86.

Olesen, J.M. 1991. Trigona-mimicking hoverflies (Diptera: Syrphidae) in the Amazonian rainforest? British Journal of Entomology and Natural History, 4: 47.

Opler, P.A. 1981. Polymorphic mimicry of polistine wasps by a Neotropical neuropteran. Biotropica, 13(3): 165-176.

Oswald, J.D. 2020. Neuropterida Species of the World. Lacewing Digital Library, Research Publication No. 1. http://lacewing.tamu.edu/SpeciesCatalog/ Main. Access: 04/2021.

Parfin, S.I. 1958. Notes on the bionomics of the Mantispidae (Neuroptera, Planipennia). Entomological News, 69(8): 203-207.

Parker, F.D. \& Stange, L.A. 1965. Systematic and biological notes on the tribe Platymantispini (Neuroptera: Mantispidae) and the description of a new species of Plega from Mexico. Canadian Entomologist, 97(6): 604-612.

Penny, N.D. 1982. Neuroptera of the Amazon Basin. Part 6. Mantispidae. Acta Amazonica, 12(2): 415-463.

Penny, N.D. \& Costa, C.A. 1984. Mantispídeos do Brasil (Neuroptera: Mantispidae). Acta Amazonica, 13(3/4): 601-687.

Poulton, E.B. 1890. The colours of animals: their meaning and use, especially considered in the case of insects. New York, Appleton \& Co.
Rasmussen, C. 2009. Diversity and abundance of orchid bees (Hymenoptera: Apidae, Euglossini) in a tropical rainforest succession. Neotropical Entomology, 38: 66-73.

Rasmussen, C. \& Camargo, J.M.F. 2008. A molecular phylogeny and the evolution of nest architecture and behavior in Trigona s.s. (Hymenoptera: Apidae: Meliponini). Apidologie, 39: 102-118.

Rasmussen, C. \& Gonzalez, V.H. 2009. Abejas sin aguijón del Cerro Escalera, San Martín, Perú (Hymenoptera: Apidae: Meliponini). Sistemas Agroecológicos y Modelos Biomatemáticos (Tarapoto), 2(9): 26-32.

Rasmussen, C. \& Skov, C. 2006. Description of a new species of Euglossa (Hymenoptera: Apidae: Euglossini) with notes on comparative biology. Zootaxa, 1210: 53-67.

Redborg, K.E. 1998. Biology of Mantispidae. Annual Review of Entomology, 43: 175-194.

Redborg, K.E. \& MacLeod, E.G. 1985. The developmental ecology of Mantispa uhleri Banks (Neuroptera: Mantispidae). Illinois Biological Monographs, 53: $1-130$.

Reemer, M. 2010. A second survey of Surinam Syrphidae (Diptera): introduction and Syrphinae. Tijdschrift voor Entomologie, 153: 163-196.

Reemer, M. 2012. Unravelling a hotchpotch. Phylogeny and classification of the Microdontinae (Diptera: Syrphidae). Doctoral Thesis, Faculteit der Wiskunde en Natuurwetenschappen. Leiden, Leiden University. 384p.

Richards, 0.W. 1978. The social wasps of the Americas, excluding the Vespinae. London, British Museum (Natural History).

Rogenhofer, A.F. 1862. Beitrag zur Kenntniss der Entwicklungsgeschichte von Mantispa styriaca Poda. (pagana Fab.). Verhandlungen der ZoologischBotanischen Gesellschaft in Wien, 12: 583-586.

Roubik, D.W. 1989. Ecology and natural history of tropical bees. New York, Cambridge University Press.

Salt, G. 1929. A contribution to the ethology of the Meliponinae. Transactions of the Entomological Society of London, 77: 431-470.

Schwarz, H.F. 1948. Stingless bees (Meliponidae) of the western hemisphere. Lestrimelitta and the following subgenera of Trigona: Trigona, Paratrigona, Schwarziana, Parapartamona, Cephalotrigona, Oxytrigona, Scaura, and Mourella. Bulletin of the American Museum of Natural History, 90: 1-546.

Shelford, R.W.C. 1902. Observations on some mimetic insects and spiders from Borneo and Singapore. Proceedings of the Zoological Society of London, 1902[2]: 230-284, pls. 219-223.

Silva, A.C. \& Gil-Santana, H.R. 2004. Predation of Apiomerus pilipes (Fabricius) (Hemiptera, Reduviidae, Harpactorinae, Apiomerini) over Meliponinae bees (Hymenoptera, Apidae), in the State of Amazonas, Brazil. Revista Brasileira de Zoologia, 21: 769-774.

Smith, B.H. \& Roubik, D.W. 1983. Mandibular glands of stingless bees (Hymenoptera: Apidae): Chemical analysis of their contents and biological function in two species of Melipona. Journal of Chemical Ecology, 9: 1465-1472.

Smith, F. 1863. Descriptions of brazilian honey bees belonging to the genera Melipona and Trigona, which were exhibited, together with samples of their honey and wax, in the brazilian court of the international exhibition of 1862. Transactions of the Entomological Society of London, 11: 497-512, plate 420.

Snyman, L.P.; Ohl, M.; Pirk, C.W.W. \& Sole, C.L. 2020. A review of the biology and biogeography of Mantispidae (Neuroptera). Insect Systematics and Evolution, 52(2):125-166. D0I

Walker, F. 1853. List of the specimens of neuropterous insects in the collection of the British Museum. Part II (Sialidae-Nemopterides) London, British Museum (Natural History).

Wallace, A.R. 1867. Mimicry, and other protective resemblances among animals. Westminster Review, 88: 1-43. 
Wallace, A.R. 1889. Darwinism: An exposition of the theory of natural selection, with some of its applications. London, Macmillan \& $\mathrm{C}$.

Wattanachaiyingcharoen, W. \& Jongjitvimol, T. 2007. First record of the predator, Pahabengkakia piliceps Miller, 1941 (Reduviidae, Harpactorinae) in the stingless bee, Trigona collina Smith, 1857 (Apidae, Meliponinae) in Thailand. Natural History Journal of Chulalongkorn University, 7(1): 71-74.
Westwood, J.0. 1867. Descriptions of new species of Mantispidæ in the Oxford and British Museums. Transactions of the Entomological Society of London, 3 Series, 5: 501-508.

White, A. 1841. Description of a South American wasp which collects honey. Annals and Magazine of Natural History, Ser.1, 1: 315-322.

Wille, A. \& Michener, C.D. 1973. The nest architecture of stingless bees with special reference to those of Costa Rica. Revista de Biología Tropical, 21(Supl.): 9-278. 